実際の構造物あるいは機械部分の受ける変動応力は 単純な繰返し応力ではならので, 疲労強度に基すいた 設計あるいは寿命の推定を行うには，その実物あるい は類似の実物の使用状態に和ける材料ををは構造要素 の受ける応力の变化状況を測定し，乙れを統計的沉処 理して, そのものの全寿命中に受ける变動応力の回数 を求め, 乙れと等価な重複応力による疲学試験を行つ て求めを疲労強度を基礎とするのが最も合理的な行を 方である。その理想に近すくためには，使用状態飞利 ける応力の变化状況を記録しなければならない。それ には各種の記録式歪計, 特に近来は抵抗線歪計とオッ シログラフ記録装置が用ロられているが，ての記録よ り応力変化を一々拾らととは大变な労力と時間を要す るととである。ことに長時間の記録を取るととは資材 の消耗もさるととながら，その解析整理は膨大な手数 在必要とし，人力の耐ええない場合も少なくない。

後述のようと手動ではあるが，法とんぞ頭脳を用い ずルオッシログラフ記録を機械的飞解析する装置も工 夫されているが，それによる場合も相当の注意力の集 中と学力を必要とする。乙礼を一段進めて, 歪計自体 で歪, したがつて, 応力の最大值あるいは振幅などを 幾段かのレベルイ分類し, 各レベルの出現した回数を 自動的に計数して直ちに表示するものがあれば非常に 便利である。乙のような作用を行うよう亿作られを歪 計を応力頻度計とか応力計数計と称する. 伈力の語を 歪と置らたものも同義である。

応力頻度計は最初は比較的構造の原始的なものが考 案されていたが, 近来はきわめて巧妙な機構のものが 出現してをて, 一応, 基本的な構想としては各種の型 が出揃つた感がある。現在までに出現したものは未だ 性能, 特に計数速度が充分大でない点に不満がないで はないが，乙れらが解決すれば応力頻度計の適用は一 段と広まるものと考元られる。

以下, 各種の応力頻度計飞つき解説するとととする が, 応力頻度計で問題としているのは応力または歪の

* 原稿受付 昭和 31 年 8 月 6 日

** 正員 鉄道技術研究开
レベルであるので, 文中単に応力といつている場合, 応力のレベルを意味する場合の多いととを了承願いた b.

\section{1. 最大応力頻度計}

応力頻度計として, ます最初飞考光付くのは応力変 化の最大值を計数するものである.その例はGoodyear Aircraft Corp. の応力変化記録装置である. 構造は第

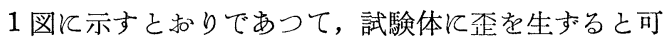
動片が本体に対して相対変位をなし，（b ）に示すレバ 一がピボットの周囲に迴転する。とのレバーの 1 動き により計数装置のラッチェット・ホイールを 1 歯送る

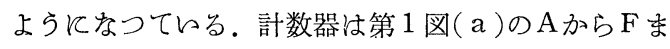
であるが，その 1 送りは順次歪の大さに対応する。こ の計器では応力レベルは幾何級数 $(1.5$ 倍ずつ)になつ ている.さらに, 引張応力に対しては第1図(c)の右 に示すように上のカムがはそらを, 圧縮応力に対して は中の図のように下のカムがはたらくようにしてあつ て, 圧縮応力の疲労効果が引張応力のそれ比して小 さくなるとと補正するようにしてある。帛和，第 1
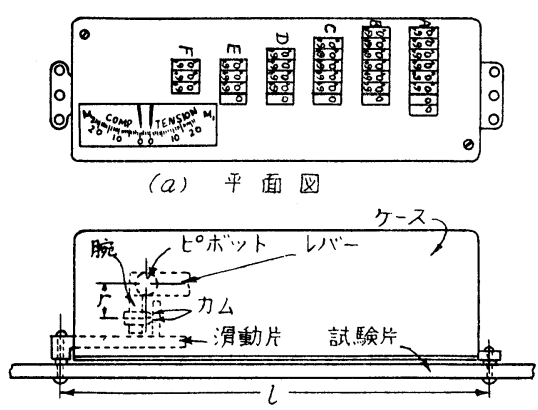

(b) 側面国

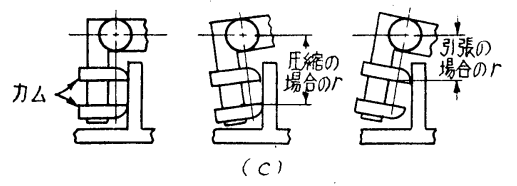

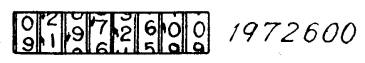

(d)

第 1 図 
図( a )の左端にある目盛は置針式の応力計で，乙の装 置を取付けた後の最大引張和よび最大圧縮応力を読む ようになつている。これに用いている計数器は作動力 を小にするため跳躍式でなく連続型であるので読み難 々点がある。第1図( d ) にその読み方の一例を示す。

この種の応力頻度計で計数装置を電磁カウンターに

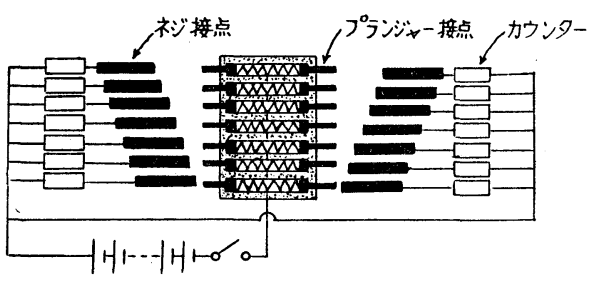

第 2 図
したものに Vickers-Armstrong Ltd. のものがある. この作動原理は第 2 図に示すとおりであつて, 中央の ばねで外へ押着けられているプランジャ一接点が歪計

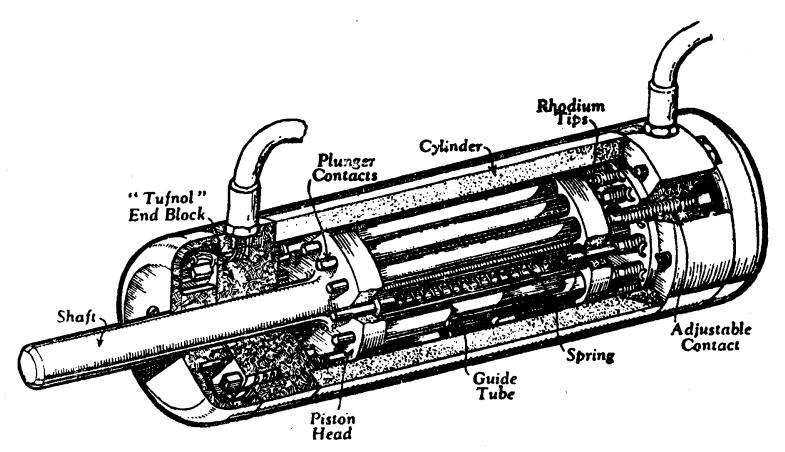

写 真 1 .
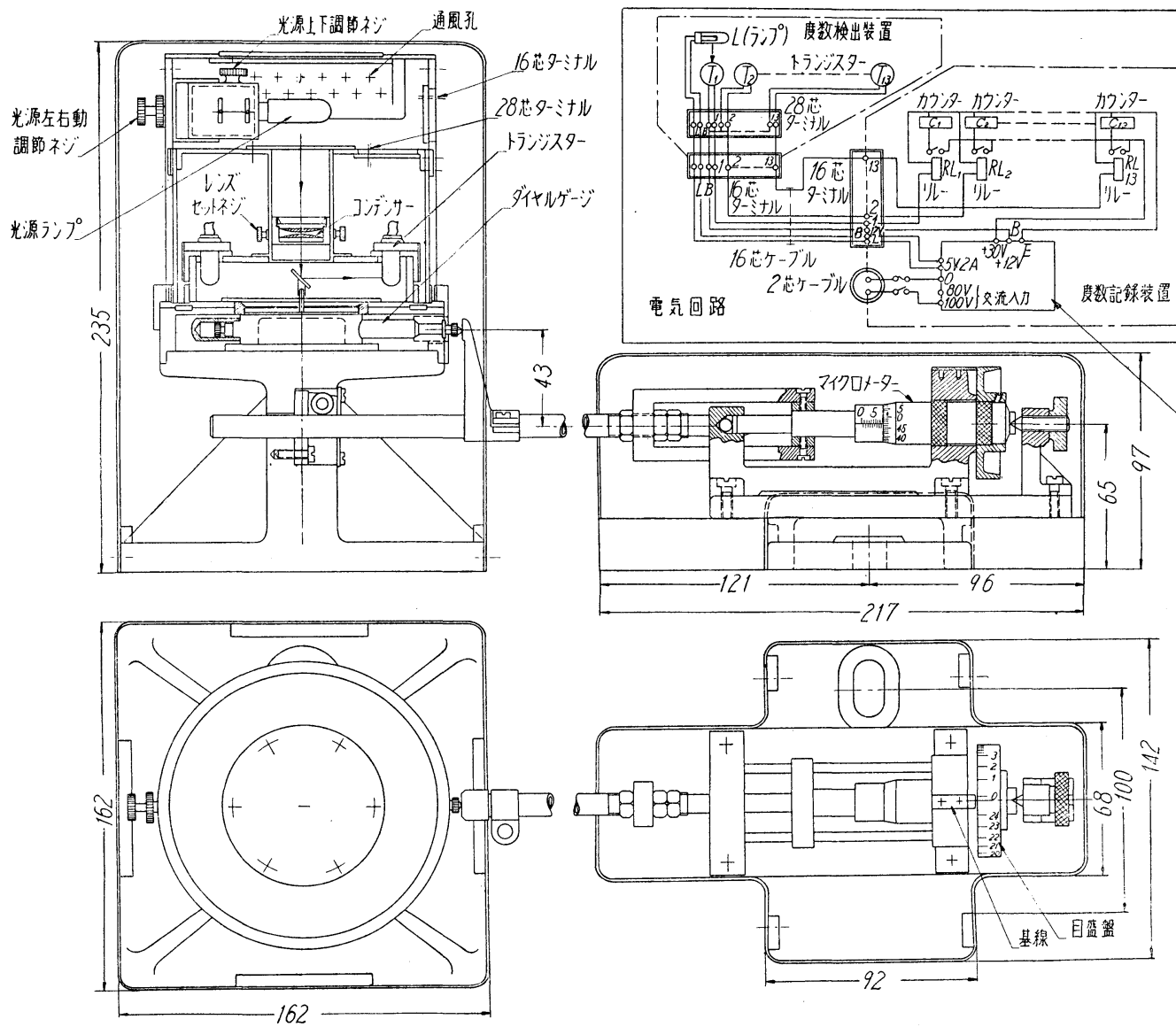

第 3 図 
の可動部に連なつている。乙れが両外側にある歪計固 定部の接点に接触するとカウンターが計数する。片側 は引張応力に対する接点であり，他の側は圧縮応力に 対する接点である。乙れらの数組の接点はあらかじめ 数段の応力に調整して置けば, その応力に達すると力 ウンターがはたらくわけである。実際の構造は写真 1 に示すと和りである。

この歪計は何ら拡大装置を設けられていないから， 標点距離は相当大でなければならない。

運輸技術研究所ではダイヤルゲージ型の歪計のダイ ヤルゲージ指針で電磁カウンターを作動せしめるもの と, 光走光トランジスターに入れて計数せしめる石黒 式応力頻度計の 2 種類のものを試作している. 後者の 構造を第 3 図に示士.

われわれの研究室で注接触式歪計から発展せしめた 第4図のようなものを作つている。標点距離は 100 $\mathrm{mm}$ で, 応力頻度計としては小型のものである. 可動 標点 $\mathrm{A}$ の動きが制形支点 Bで支えられたレバーの先端 の拡大された動きとなりレバー端て設けられた接点 $\mathrm{C}$ が対応する接点 $\mathrm{D}$ と接触し, カウンターを作動せし める。Dはマイクロメーターで微動するレバー端に設 けられてあるので，接触応力は微細に調整でをるよう になつている。接点の接断を上あるいは下向をのパル スとして抵抗線歪計のオッシログラフ記録上に入れた
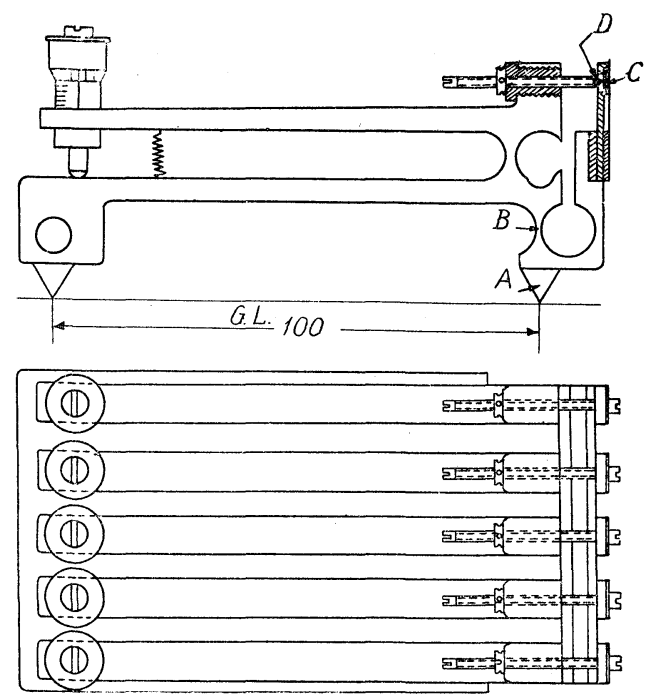

第 4 図
ものを第 5 図に示すが，その接断は相当よい精度で同 一応力で生じているととが恋められる。

これらの型式の最大応力頻度計は計数器の機構上, 応力が 1 方向, そとえば, 增加する方向に進む場合計 数して, 反対方向に進む場合は計数しないのが普通で ある、また，ある応力から他の応力まで変化すると， その間の応力は全部計数する。したがつて, 最小応力 と最大応力の中間で変動すると, その中間の応力の計 数が増加する。乙れを利用すると中間の応力变動の状 況もある程度知るととがでさる。

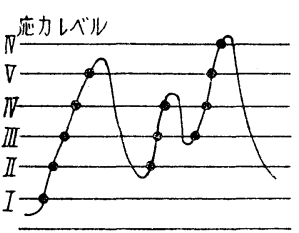

(a)

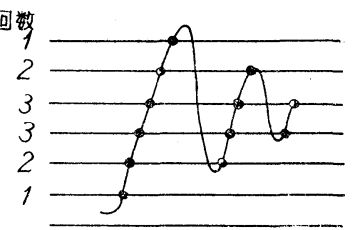

(b)
第 6 図

しかし，これを系統的に単純に解析したものが必ず しも真の応力变化の状況を表わすととにはならない. 第 6 図 $(a)$ 示す応力变化は中央飞示すカウンターの 計数值となるが，乙れを系統的に単純に解析すると第 7 図(b)のよう飞なり，波形が異なつをものとなる。 一般的浮大応力頻度計の結果を系統的飞単純飞解析 すると簡単な形になる。

この型式の最大応力頻度計の根本的の難点は, 歪計 と測定体に温度差を生じたり，あるいは測定体に温度 応力を生ずると応力の基準点, いわゆる零点が变化す るととである。実際問題としてとの種の機械的歪計の 本体の温度を測定体のそれと一致せしめるととは不可 能である。われわれが鉄道橋で実測しそ例によると， 零点の变動は第 7 図に示すようになつた。疲労強度の 第 1 主要因子は応力振幅であり, 平均応力はこれに比

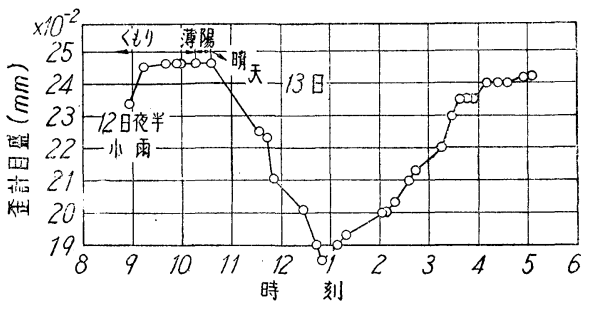

第 7 図

すれば影響は小であるととを考えると， 零点变化を避计難々場合はむしろ次に述 ベる応力振幅頻度計を用いそ万が得策の よらである。

\section{2. 応力振幅頻度計}

応力変化の平均值の々かんにかかわら
第 5 汹 


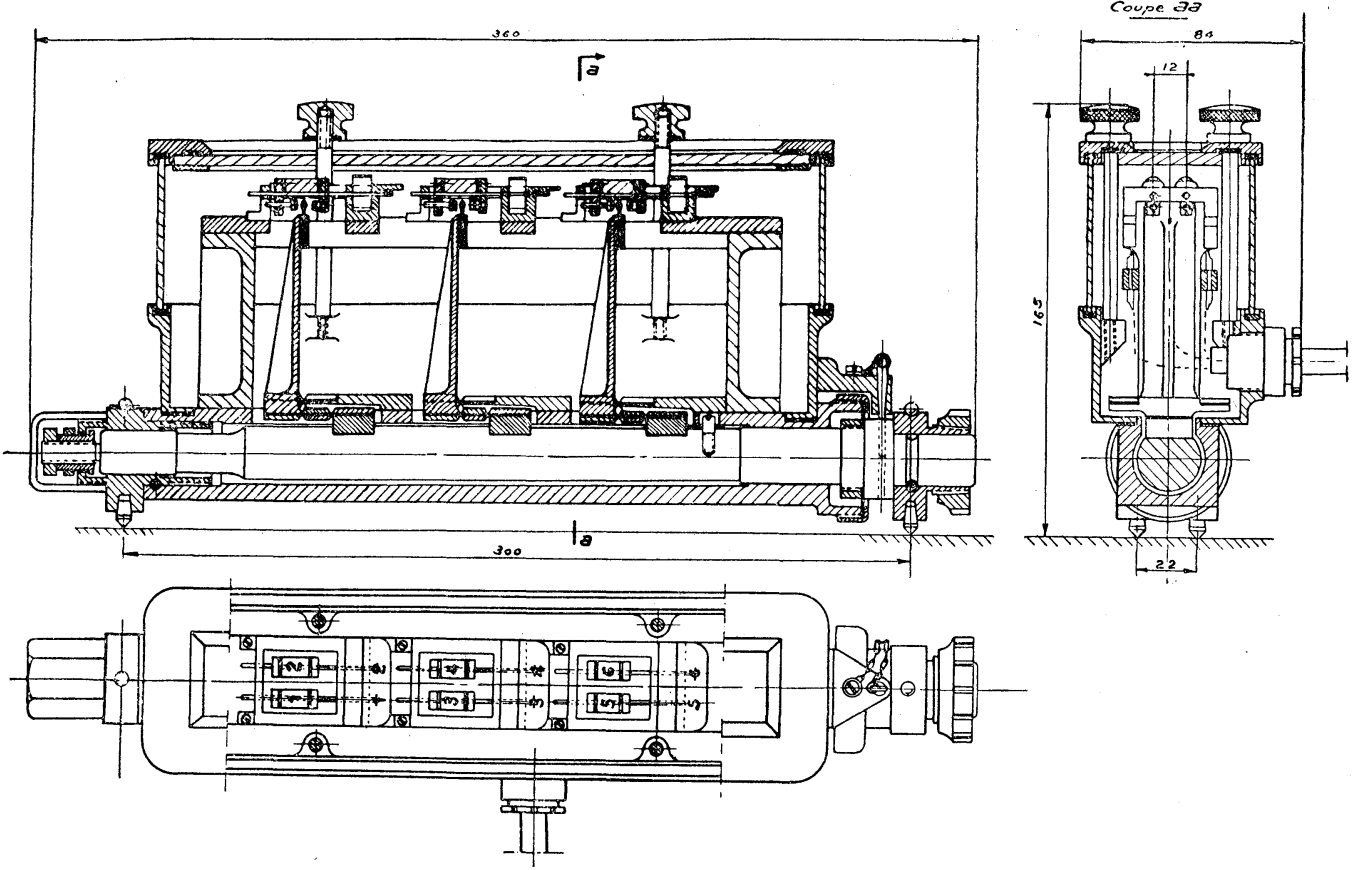

第 8 図

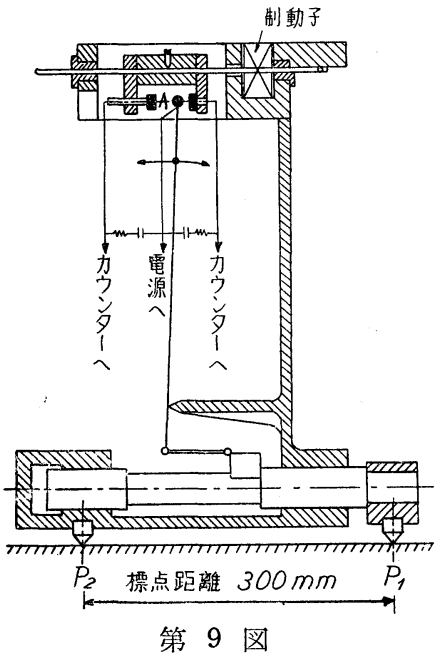

第 9 図

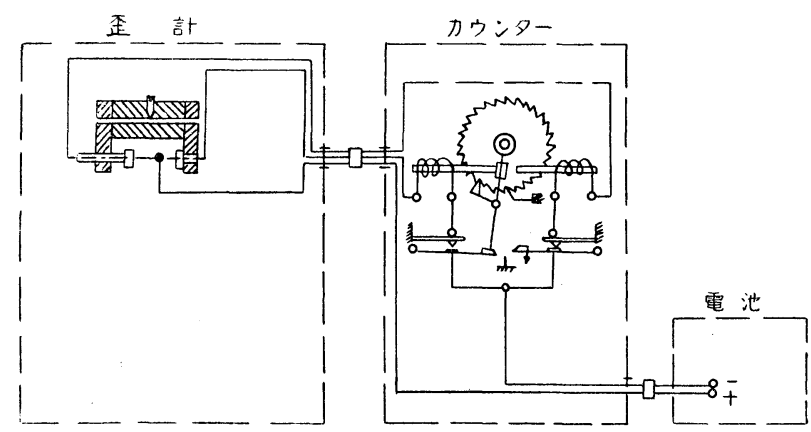

第 10 図
す応力振幅(全振幅を意味する)のみの頻度を計数する ものを応力振幅頻度計と称する。第 8 図汇示すものは de Leiris の船舶用の応力振幅頻度計で西る。乙の作 動原理を第 9 図について説明すると, 可動標点 $\mathrm{P}_{1}$ の 動きがレバーで拡大され，レバー端に設けそ䨓気接点 が応力振幅に対して設定した 2 箇 1 組の接点に接触す る.との 2 箇の接点を取付けたフォーク枠は, 取付け そ軸と共にレバーで押されると自由に滑動するように してあるが，レバーが離れると制動子の祭擦でその位 置飞止る。電磁カウンターは第10图に示す構造となつ ていて, 歪計の 1 組の接点が交互飞接触すると，すな わち所定の振幅在生ずると 1 回計数する. 実際のもの はこのような接点が 6 組設けてある。との電磁カウン タ一の変わつている点は, 一方の電磁石飞電流が通じ, ラッチエット送りが動くと，下沉設けそクリップ装置 でクリップすると同時に電流を切つてしま うようになつている点であつて, これによ り接点が接触していても電流は流れす，無 用の電池消耗を防ぐことがでをる。

との応力振幅頻度計では, ある振幅飞対 しそれ以下の振幅のカウンター注全部作動 するが, 各振幅の回数は值上の回数を引く ととにより容易に求めるととができ, 紛れ を生和当ととはな⿰。

この種のものとしては後述の TMB 頻度 計が同じ目的にも使用できるようになつて 
レる.

\section{2 元応力頻度計}

応力変化をより完全飞知るには応力振幅と平均応力, あるいは最大応力と最小応力の組合わせを知る必要が ある。今まで述べを応力頻度計は最大応力あるいは応 力振幅なる 1 元量の頻度を求めるものであつたが，上 記の目的には応力の 2 元的組合わせを頻度計数するも のでなければならなら，乙れを実現した応力頻度計を 総称して 2 元応力頻度計とし, その中で最小応力と応 力振幅を表示するものを最小応力一振幅頻度計, 最小 応力と最大応力の組合わせを表示するすのを最小一最 大応力頻度計などと呼んではどうであろらか。

との型の最初のものは David Taylor Model Basin で作られた TMB 応力頻度計である。この原理は第11 因に示すよう亿最大応力頻度計と応力振幅頻度計を組 合わせをようなものである. 応力振幅計の滑動枠が最 大応力の位置で置き去りにされ，次に最小応力の接点 飞接触子が当るとカウンターは作動する。この場合，
接触子は帯レベル接点を摺動して行くから, その带レ ベル飞対応するカウンター群中のその振幅住対応する ものが計数する，すなわち最小応力と振幅の組合わせ のカウンターが作動する．最小応力に振幅を加えると 最大応力が得られるから，とのカウンタ一群を最大応 力一振幅の組合わせとして見るととも容易である。あ る振幅の場合, これ以下の振幅のカウンターが全部作 動するとと, したがつて, 計数の修正法は振幅頻度計 の場合と全く同一である。との計器て使用されている 電磁計数回路は複雑であるのでここには説明死省略す

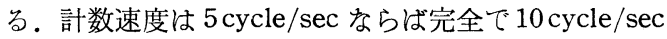
では相当不完全になると報告されている。

今まで述べを応力頻度計は歪計部は機械的で, 計数 装置はほとんぞ電気的であつたが，最近オランダで作 られた船船用最大一最小応力頻度計は抵抗線歪計を使 用している点とカウンターの選別回路が主として電子 管によつている点で特長のあるものである。その作動 原理は第12図から第14図炕示すようである。抵抗線歪

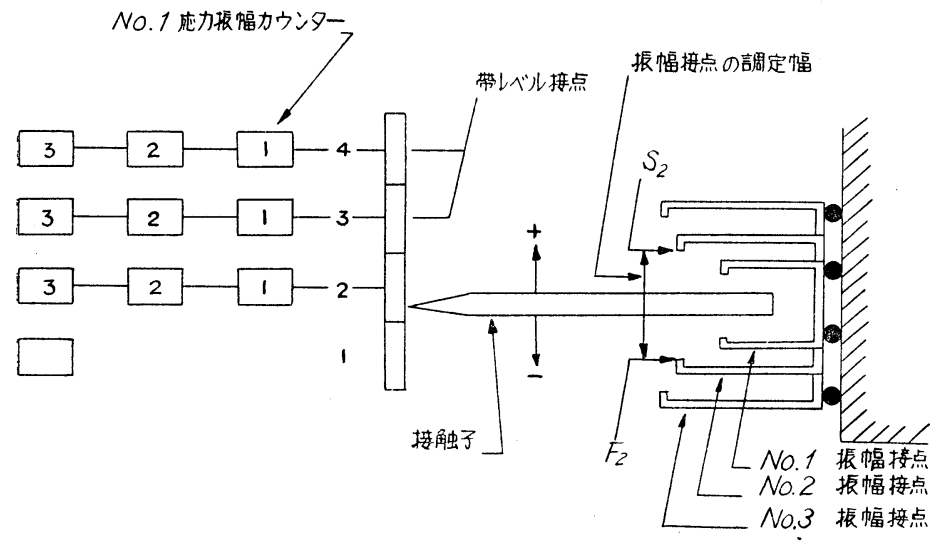

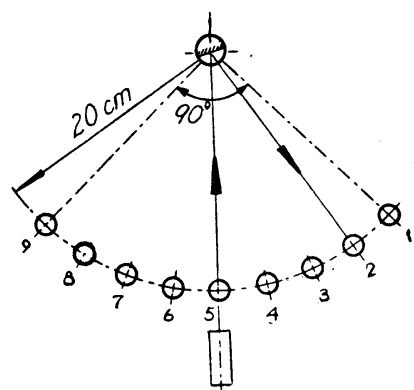

第 12 図

第 11 図

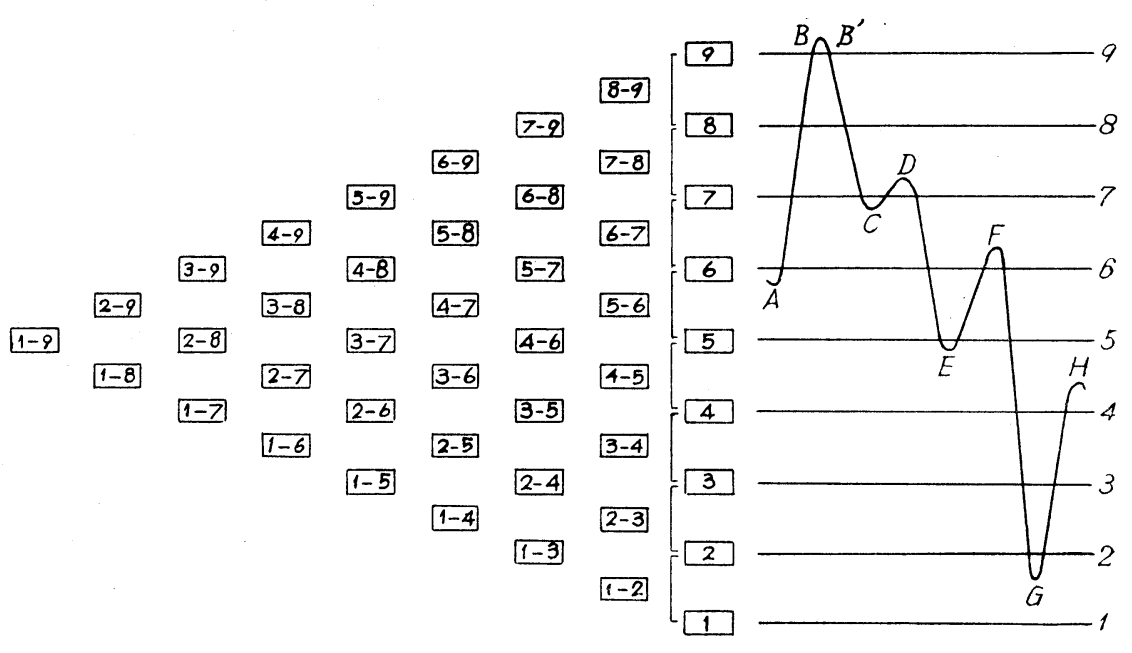

第 13 図 


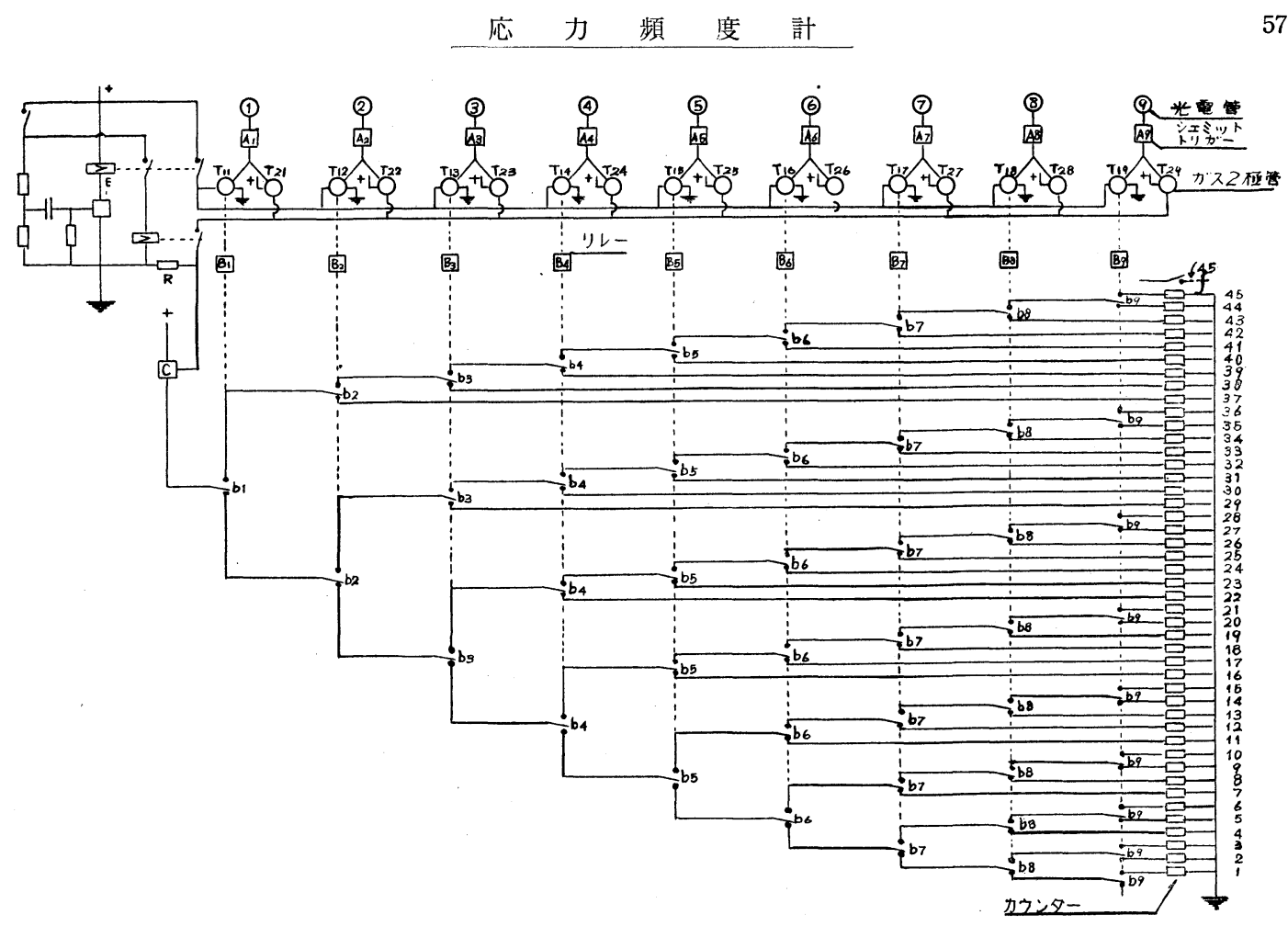

第 14 図

計の出力は增幅器なしで高感度ガルバノメーターに入 れられる.ガルバノメーターからの光線は第14図に示 すように応力別に配置した光電管に入る. 応力の組合 わせに対するカウンターの配置は第15図に示すように なつている.との作動は次のようにして行われる。最 初 $\boldsymbol{n}$ 番目の光電管が光を受けると, それに接続してい るトリッガー $\mathrm{A}_{n}$ が作動し, ガス 3 極管（サイラトロ ン) $\mathrm{T}_{1 n}$ が点火し，これによりリレー $\mathrm{B}_{n}$ がはたらき， $\mathrm{B}_{n}$ 群に属するカウンター回路は全部上に接続する. しかし，この状態では未だ Cは通電状態となつていな レのでカウンターは作動しない. 次に $n+1$ 番目の光 電管飞光が当ると同様に $\mathrm{B}_{n+1}$ 群に属するカウンター 回路が上に接続する。したがつて, $\mathrm{B}_{n}, \mathrm{~B}_{n+1}$ 群に共 通な特定のカウンターが作動待機姿勢となる。このレ ベルで応力が最大となつたとすると, 光線は戻つて再 び $n+1$ 番目の光電管に当る. $T_{1 n+1}$ で既に点火して レて再びトリッガー回路がはたらくと $\mathrm{T}_{2 n+1}$ が点火す る. $\mathrm{T}_{2}$ のサイラトロンは全部抵抗 $\mathrm{R}$ を通つているの

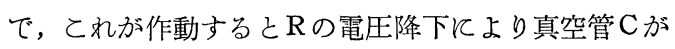
通電状態となりカウンターがはをらく，各カウンター には扣の抄の古るスイッチが入つていて, カウンタ 一がはをらくと $\mathrm{T}_{1}$ 群のサイラトロンは全部消える。 次㳻れて $\mathrm{T}_{2 n+1}$ が消え, カウンター電流は切れ同時 に $\mathrm{T}_{1 n+1}$ が点火するようになつている。このようにし て計数が終るが, その時の応力位置は記憶されている 訳である。これから応力が下つてきて最小応力達す
ると, 先に述べをと全く同様の経過で $n+1$ なる最大 応力と達した最小応力との組合わせのカウンターが作 動し, その時の最小応力を記憶する. 要するに応力の 極值で 2 回連続のパルスを生ずるととにより計数と記 憶を与える巧妙な方法をとつている。との頻度計では 最小から最大に至るものと，最大から最小に至るもの とを全く同様に計数するが，とれは他の頻度計と異な る点である. 計数速度は 1 レベルの变動に対し 10 cycle/sec であつて, この計器の 9 レベルでは 111 cycle/sec となつている.

これらの 2 元応力頻度計では 2 元量の計数表示とな るので, 応力レベルの数を $n$ とすると, $\sum^{n} n$ の計数器 を必要とする。したがつて, 電気部品の数も多く、レ ベル数を増すと急增する。しかし, 变動応力のより完 全なる表示はこれによるほかはなく，応力变動城の広 ら昜合はこれによらざるをえないものである。

\section{4. 応力記録解析装置}

以上述べを応力頻度計は，はなはだ便利なものであ るが, 今のととろ計数速度はせいぜい $10 \mathrm{cycle} / \mathrm{sec}$ 止 りであるため，その適用籁囲は变動速度のあまり速く ないもの,たとえば, 船舶の航行中の応力測定などに。 限定されている. 变動速度の早い場合はオッシログラ フ記録によるほかはない.オッシログラフ記録を解析 するに自動的に行うものができれば便利であるが，現 在は半自動的に行うものがあるだけである。これには 応力頻度計と同様 3 種類の型が考えられるが，今まで 
に発表されているものは最大応力型と 2 元応力型の 2 種類である。応力振愊型のものが\%らのは，オッシ口 グラフ記録では零点変動が判読できるてめ, 沁力頻度 計ほどその有效性がをいでと，2元応力型の製作が そう困難でないためである。

最大応力型の例㹥金子計器製作所の $\mathrm{KS}$ 式頻度計数

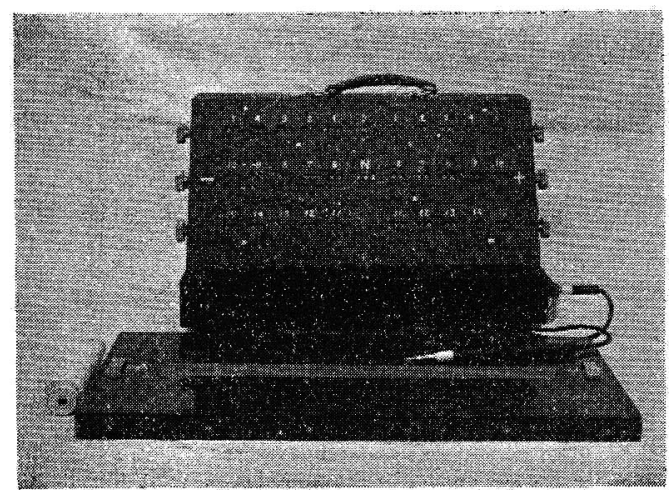

写真 2 .
跡してををとすると，とれから後は滑動台の押上げに 移る。 ハンドルを上浙すと電源が入り閉鎖装置が作 動して図の上方のスイッチ年 1 简接続する. その選択 は接触子の接触しているレベル予備選択接触片の位置 により決まり，図の場合はレベルII飞対応するスイッ 千II が入る。レベル予備選択接触片は速続的に並んで ロるので接触子が移動して行つても電流の切れるとと がなく，そのそわ接触子が III，IV・と移つて行つて もスイッチは II の位置で入つそままで III, IV.. と は移らなら，滑動台が拥上げられるこIIの回路に入つ てレるカウンターは $2,3 \cdots$ のレベル通過接触片の電 流の断続により計数する. 最大応力に達して後はレバ 一が押下げの方向に動くので電源㕝切り最初の状態に 戻る. カウンターの横の列は最大応力, 縦の列は最小 応力を示し，その組合せの位固で 2 元応力が決まる。

最小值加ら最大値飞至る間は，その最小値飞対応す る最大值までのカウンターは全部はをらくから, 前に も述へえようと, 計数值は直上のカウンターの計数值 を引らたもので示され

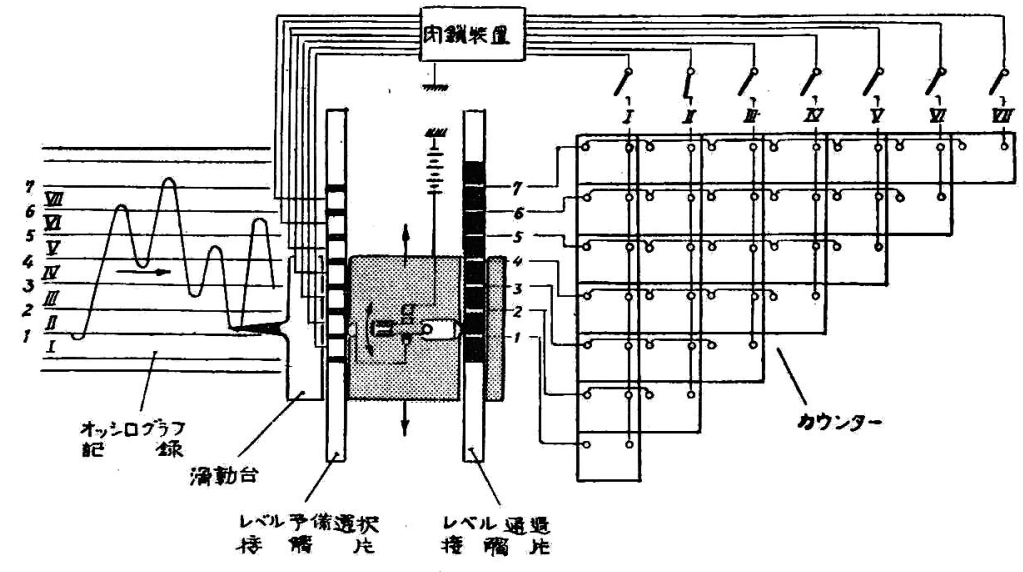

第 15 図 る。

この存が，カウンタ 一の代り《統計機のパソ チカードス穿孔するすの も作られているが構造は 明らかで福。

\section{5. 応力頻度計の} 精度

応力变化の振動数があ まり大でなく，応力が調 定したレベルを充分高く 超光る場合壮頻度計の数 え落しは质とんどなく， de Leiris の奏験で最大

器であるが，これは $1 \mathrm{~mm}$ 和变飞分割して解析板と称 する敛属板上飞記録を載せ，探索棒と称する針で記録 の山まれは谷を突的て行くと，針は記録架乫抜を対応

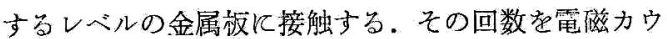
ンターで読むものである。記録の山または谷をどんど ん突的て行くだけでよロので操作は早い. その外形を 写真 2 示す.

2 元応力型のものは Svenson の述べている第15図 に示すものがある。この作動てついては彼は説明して らないが，TMB 応力頻度計と似ているところからし て次のようであらうと推察される。記録は右加ら左へ と送られる。これ党滑動台の中央にあるハンドルを上 下して指針にて追跡する。ハンドルを下に押す時は電 源は断をれていてカウンターもスイッチの閉鎖装置も はをらか子、今, 因のようと最小応力の位置まで追

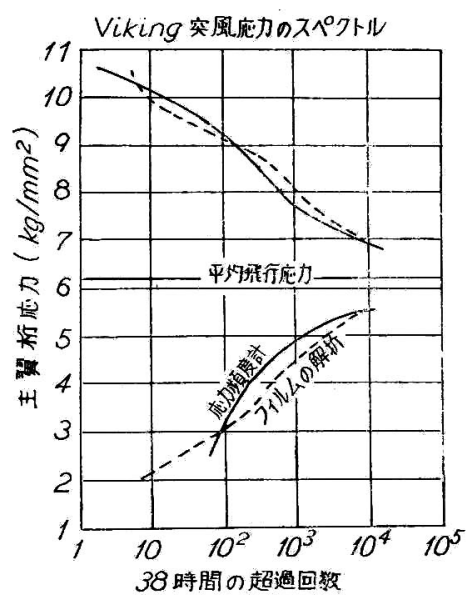

第 16 図 
$7 \%$ あり, TMB 応力頻度計では数万分の 1 であ る. しかし振動数が大であつてりり, 調整レベルすれ

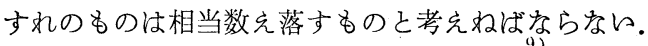
このととはわ礼わ祅の鉄道橋に和ける実験でもはつき り認められる. Armstrong-Vickers の最大応力頻度 計を Viking 飛行機の主翼桁にとりつけ, 定期航空の 突風試験を行つを結果は, 第16図に示すようにオッシ ログラフ記録を解析しそものと大差なく，とのような 応力頻度計の精度の良好なととを示している。

$$
\text { 6.むむず }
$$

既に述べをように，応力頻度計はなかなか巧妙な機 構のものが出現していて, 応力変化の詳細な統計的調 查の可能となるのも近いようである。国際溶接会議 (I.I.W.) では溶接構造物の疲学破損の調査と関連して 応力頻度計の取付けを推進しようとしている。 今まで は疫労実験のデータの集積されている割合に，実測応 カのデータは少なかつた。 しかし応力頻度計が盛んに 利用されるようになると, 複雑な変動応力のデータが 容易飞手に入るようになるが, 疲労実験の方は変動応 力に対してはせいぜり簡単な重複荷重で対抗する程度
で, 複雑な変動応力に対応する力を失いはしないかと 心配である。疲労実験の方でも变動応力痏労試験機を 作り，今から明日の事態汶対処する準備を整光るとと が必要のととと思われる。

注: 一

1) M. Hetényi, Handbook of Experimental Stress Analysis. p. 108, (1950), Good year Stress Change Recorder.

2) J.B. Lambie, The Counting Strain Gange. Engg., Vol. 174, p. 168 (1952)

3) A. Thum, \& C. Svenson, Kontakt-Dehnungsmesser zum Messen von Betriebsbeanspruchen. VDI. Vol. 88, S. 153 (1944)

4) H. de Leiris, La ditermination statistique des contraintes subies par le navire a la mer. Assoc. Tech. Mari. Aeron. Session (1956)

5) N.H. Jasper, The TMB Strain Cycle Gage and Counter. Proc. soc. Exp. Stress Analysis. Vol. 10, No. 1, p. 87 (1952)

6) C.J.D.M. Verhagen, J.C. de Does, A Special Stress Analyser for Use on Board Ship. Intern. Shipbuildg. Progress, Vol. 3, No. 21 (1956)

7) K. Fink, Grundlagen und Anwendungen des Dehnungsmessstreifens, Düsseldorf S. 136 (1952)

8) Consolidate Engg. Corp. and other catalogues

9) 1956 年 9 月,学術会議橋梁, 橉造工学研㶢連絡委員会講演会予定

\section{オイルシールにおける二三の問題*}

1.はしがき

目覚しい科学の発達とともに, 近時鉄鋼界をはじめ 諸産業の生産その他は戦前を上回る実績を示してい る。したがつて，乙れら技術水準の向上とともと諸機 械機器はより高速度高圧化へと進み, その軸受部の稼 動率の上昇, 潤滑剤の合理的利用などはますます重要 視されつつある。

さて, オイルシールという名称で軸受の密封装置が わが国澄場してより十有六年余り，らよいよ市昜に 大をな認識を持ちうるようになつたのであるが，その 理論, 技術なぼについては未で解明されていない面が 多く，今後幾多の研究を必要とするのである。しかし ながら，オイルシールに和ける最も大をな問題点は，

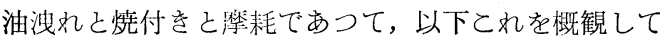

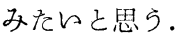

\section{2. オイルシールの分類}

かつては機械の回転軸受部に和ける軸箱と軸との空 陌飞対して単に詰物として,フェルトや系紐皮革など

* 原稿受付 昭和 31 年 8 月 28 日

**日本オイルシール工業株式会社

$$
\text { 石渡秀男** }
$$

を抑し込んで置いたのであるが，高分子材料の発澾と， 実験研究の進歩によりオイルシールとしてのある種の 型式を持つものにと前進した。

広義のオイルシールとして (i)軸シール (ii) 外面 シール (iii) 端面シール(メカニカルシール)飞大別す るととができる。

軸シールはオイルシールの中でも最も応用範围が広 く, 使用量の $90 \%$ 以上を占敉多くの変形型が製作さ れているが，その作動原理は皆同一である。主として

(A)

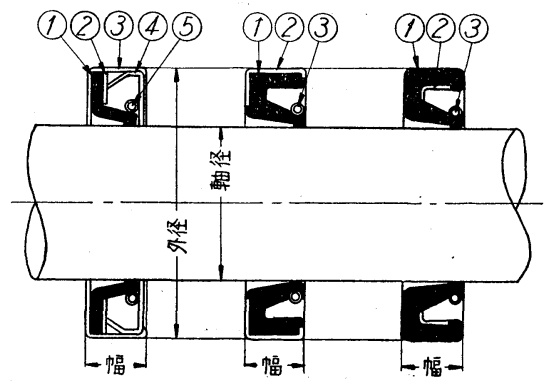

第 1 図 軸シール断面図 